\title{
NOTE
}

\section{Sulfur isotopic ratios of ore deposits associated with Mesozoic felsic magmatism in South Korea, with special reference to gold-silver deposits}

\author{
Hidehiko Shimazaki ${ }^{1}$, Hitoshi SaKaI ${ }^{2}$, Hiroaki Kaneda ${ }^{3}$ \\ and MIN SUNG LEE ${ }^{4}$
}

Geological Institute, Faculty of Science, University of Tokyo, Hongo, Tokyo $113^{1}$, Ocean Research Institute, University of Tokyo, Nakano, Tokyo $164^{2}$, Department of Mineral Development Engineering, Faculty of Engineering, University of Tokyo, Hongo, Tokyo 113, Japan ${ }^{3}$, and Department of Earth Sciences, College of Education, Seoul National University, Seoul, Republic of Korea ${ }^{4}$

(Received September 25, 1984: Accepted November 7, 1984)

\begin{abstract}
Isotopic composition is determined for ore sulfur from seventeen $\mathrm{Au}-\mathrm{Ag}$, six W-Mo and one fluorite deposits in the southern Korean Peninsula. The age of ore formation ranges from pre-Cambrian to Cretaceous. Together with the data available in the literature, the following characteristics are recognized: 1) most $\delta^{34} \mathrm{~S}$ values fall in the narrow range of +2 to $\left.+7 \% 0,2\right)$ no systematic variations are observed among the deposits of different geologic environments and with different workable metals, and 3) exceptional negative $\delta^{34} \mathrm{~S}$ values are observed in some deposits located in and near the Taebaegsan area. Predominance of ore sulfur with positive $\delta^{34} \mathrm{~S}$ values suggests the biogenic sulfur-poor nature of constituent sedimentary rocks in the Korean continental crust.
\end{abstract}

\section{INTRODUCTION}

The regional variation of isotopic compositions of ore sulfur is of great interest from the viewpoint of material source and formation mechanism of hydrothermal mineral deposits. Moreover, the recent discovery of parallelism between sulfur isotopic compositions of granitoid and genetically related ores, established in the Japanese Island Arc by Sasaki and Ishihara (1979, 1980), stimulates the study on the regional variation of isotope ratios of ore sulfur in other granitic terrains than the Japanese Islands.

In the southern Korean Peninsula, Jurassic and Cretaceous granitic rocks, called Daebo and Bulgugsa series, respectively, are widespread besides pre-Cambrian granitic gneisses (Reedman and Um, 1975). According to Ishihara et al. (1981), the former in general belongs to ilmenite series defined by Ishihara (1977), while the latter to magnetite series, although the Daebo granitic rocks tend to change gradually into magnetite series toward the north (Shimazaki et al., 1981). There are many hydrothermal mineral deposits in the southern Korean Peninsula associated with those granitic activities. Recent age dating data revealed that some productive W-Mo and base metal deposits are formed in Cretaceous time (Kim, 1971a; Fletcher and Rundle, 1977; Farrar et al., 1978; Yun and Silberman, 1979; Sato et al., 1981a; Kaneoka et al., 1983; Shibata et al., 1983; So et al., 1983a). The formation age, however, of $\mathrm{Au}-\mathrm{Ag}$ and some W-Mo deposits is still controversial. Based on similar distribution patterns and general trends between $\mathrm{Au}-\mathrm{Ag}$ veins and the Daebo granitic rocks, many $\mathrm{Au}-\mathrm{Ag}$ deposits, especially those known as the Korean type Au deposits, are considered to have been formed in Jurassic time genetically related to the Daebo activity (e.g. Kim, 1971b; Lee, 1981). Some Au-Ag and W-Mo deposits are even believed to have been formed in pre-Cambrian (see the compilation by Lee, 1981).

Several papers reported the isotopic composition of ore sulfur in base metal and W-Mo depoists (Kim and Nakai, 1980, 1982; Sato et 
al., 1981b; So and Shelton, 1983; So et al., 1983a,b,c, 1984). Except a few, most deposits studied in those papers have ore sulfur with positive $\delta^{34} \mathrm{~S}$ (CDT) values. The positive $\delta^{34} \mathrm{~S}$ trend resembles that of the ore sulfur in the magnetite series granitoids predominant regions in Japan (Sasaki and Ishihara, 1980). Thus, this fact is thought to be consistent with the hypothesis that most of the deposits are formed in relation to the Cretaceous Bulgugsa granitoids of magnetite series (Sato et al., 1981b).

With these results in mind, the present writers measured the isotope ratios of ore sulfur from seventeen $\mathrm{Au}-\mathrm{Ag}$, six W-Mo and one fluorite deposits in the southern Korean Peninsula. The location of the deposits studied in this paper is plotted in Fig. 1. Also shown in in the figure are the distribution of the Daebo Jurassic and Bulgugsa Cretaceous granitic rocks, and the tectonic zones in the southern Korean Peninsula, compiled from 1:250,000 scale geologic maps published by Korean Institute of Energy and Resources, partly modified by the present writers' observations and interpretations.

The outline of the deposits is given elsewhere (e.g. Gallagher, 1963; Shimazaki et al., 1984). Among the studied deposits, the formation age of the Daehwa W-Mo deposit (S: in Fig. 1 and Table 1) is reported as Cretaceous (Kaneoka et al., 1983; Shibata et al., 1983; So et al., 1983a). Recent K-Ar age determinations revealed pre-Cambrian formation of the Geumjeong (P), Jurassic of the Cheonbo (C), Seogyo (D) and Namchang (E), and Cretaceous of Mugug (B), Imcheon (I) and Yanghang (L) $\mathrm{Au}-\mathrm{Ag}$ deposits (Shimazaki et al., unpublished data). The Deogon (K), Gwangyang (N) and Sanggeum (O) Au-Ag deposits are present in the Cretaceous formations, and are obviously formed in or after Creraceous time. Most samples were collected through the Second Overseas Field Research on the southern Korean Peninsula carried out during the summer of 1982. Samples from the Seogyo (D) and Imcheon (I) Au-Ag, and Garisan (R) W-Mo deposits, were collected by the first author

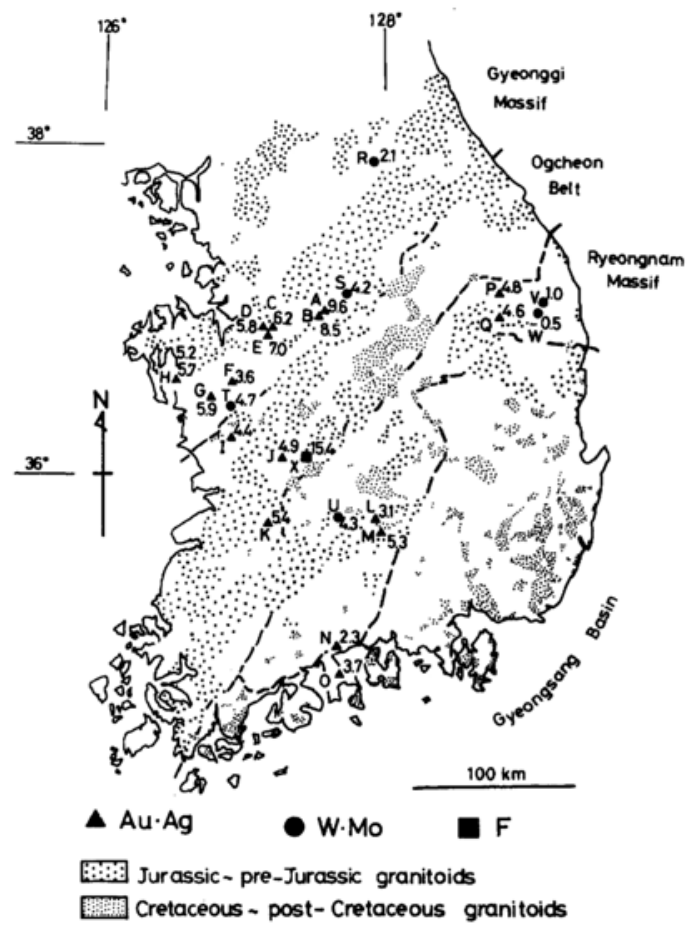

Fig. 1. Locality and isotopic compositions of ore sulfur $\left(\delta^{34} S C D T\right.$ values in per mil) of the studied deposits. Letters attaced to individual deposits correspond with those given in Table 1.

when he surveyed these deposits in June, 1981.

\section{EXPERIMENTAL}

Since the major concern here is a regional variation of ore sulfur isotopic composition, average $\delta^{34} \mathrm{~S}$ values of individual deposits were obtained by analyzing composite samples prepared from hand specimens. The number of specimens used for each composite sample is given in Table 1. Sulfur in the deposits occurs essentially as sulfide minerals, and no sulfate minerals are observed through the present study.

Sulfide minerals are decomposed by $\mathrm{NHO}_{3}+$ $\mathrm{Br}_{2}$, and $\mathrm{SO}_{4}^{2-}$ ion is precipitated as $\mathrm{BaSO}_{4}$. The obtained $\mathrm{BaSO}_{4}$ is heated with $\mathrm{V}_{2} \mathrm{O}_{5}$ and $\mathrm{SiO}_{2}$ up to $900-950^{\circ} \mathrm{C}$, and converted to $\mathrm{SO}_{2}$ by the procedure described by Yanagisawa and Sakai (1983). The mass spectrometer used for the isotope analysis has been described by Sakai et al. (1970). The results of the isotope analysis 
are given in the $\delta^{34} \mathrm{~S}$ value as defined by:

$$
\begin{aligned}
\delta^{34} \mathrm{~S}(\% 0)= & {\left[\left({ }^{34} \mathrm{~S} /{ }^{32} \mathrm{~S}\right)_{\text {sample }} /\right.} \\
& \left.\left({ }^{34} \mathrm{~S} /{ }^{32} \mathrm{~S}\right)_{\text {standard }}-1\right] \times 1000
\end{aligned}
$$

The standard is troilite sulfur from the Canyon Diablo meteorite. The uncertainty in $\delta^{34} \mathrm{~S}$ values is less than $\pm 0.2 \%$ in most cases.

\section{REsults AND Discussion}

Sulfur isotope data obtained are summarized in Table 1, and plotted in Fig. 1. The $\delta^{34} \mathrm{~S}$ values show rather wide variation from -0.5 to $+15.4 \%$, but about $80 \%$ of the values fall in a narrow range of +2 to $+7 \%$. As cleary shown in Fig. 1, the isotopic ratios of ore sulfur from the deposits of the same type which are located close to each other, are nearly identical. For example, the value $+9.6 \%$ for the Geunwang deposit (A), a kind of satelite one around the famous, large Mugug deposit (B), is close to the value $+8.5 \%$ for the latter. The ore sulfur from the Cheonbo (C), Seogyo (D) and Namchang (E) deposits reveals values around +6 to $+7 \%$, similar to each other. These three deposits are closely associated with Jurassic pegmatite dikes.

In the Gyeolseong mining area $(\mathrm{H})$, two adits, namely the Main and Geodo adits, were once operated. The appearance of the ores from the Main adit is quartz-rich and poor in other minerals, whereas those from the Geodo adit are abundant in sulfide and carbonate minerals. Under the microscope, however, the mineral assemblage in the ores from both adits is essentially the same. Sulfur isotopic compositions were measured separately on the composites of the ores from these adits, and were confirmed to be identical with each other. The values for the Geumjeong (P) and Dadeuk (Q) deposits are also very close to each other. In this case, however, the type of the deposits is quite different, that is, the gold mineralization of the former occurs in a pre-Cambrian alaskite (quartz - K-feldspar) dike and that of the latter in usual quartz veins. The Ssangjeon (V) and Ogbang (W) W-Mo deposits are situated closely, and have relatively light ore sulfur. These fea- tures on the isotopic compositions of ore sulfur, are recognized also by Sato et al. (1981b), who applied almost the same procedure as the present study to the samples from 22 hydrothermal $\mathrm{Cu}-\mathrm{Zn}-\mathrm{Pb}$ and W-Mo deposits in South Korea.

The opaque minerals observed in the composite samples are also listed in Table 1. As in the case of $\delta^{34} \mathrm{~S}$ values, mineral assemblages are almost identical among the $\mathrm{Au}-\mathrm{Ag}$ deposits situated closely to each other. For example, the assemblage pyrite-arsenopyrite predominates in the deposits located in the northern parts (mines A to $\mathrm{H}$ and $\mathrm{P}-\mathrm{Q}$ ), while pyrite only or pyrite with sporadic pyrrhotite or arsenopyrite predominates in the south (mines I to O). This mineral assemblage change may be related to the general trend of $\delta^{34} \mathrm{~S}$ values of the $\mathrm{Au}-\mathrm{Ag}$ deposits from the north to the south, that is, heavier in the north as $+9.6 \%$ and lighter in the south as $+2.3 \%$. Pyrrhotite is observed in some $\mathrm{Au}-\mathrm{Ag}$ deposits. The FeS contents of sphalerites from these deposits, however, are less than twenty mole per cent, demonstrating that pyrrhotite occurs sporadically in the deposits, not being equilibrated with sphalerite (Mizuta et al., 1984). The presence of pyrrhotite could not be taken as the evidence of relatively reducing environments achieved at the time of mineral precipitation in these deposits. Thus it is quite difficult to estimate the redox environments, and also to estimate ionic species of sulfur, in the hydrothermal solutions responsible for these $\mathrm{Au}-\mathrm{Ag}$ deposits.

A heavy isotopic composition of sulfur, $+15.4 \%$, from the Jinrag fluorite deposit (X) is worthy of note. The deposit is of replacement type in limestone and granite gneiss. The occurrence of chalcedonic quartz in the deposit suggests shallow formation at lower tempratures, just like many other fluorite deposits in South Korea (Shimazaki et al., 1981). In Japan, this type of deposits is known as the Hiraiwa type, and their distribution is restricted to the regions where ilmenite series granitoids prevail (Sato, 1980). Unfortunately no sulfur isotope data are available on the fluorite deposits in 
Table 1. Sulfur isotope composition of composite samples from South Korean Au-Ag, W-MO and F deposits

\begin{tabular}{|c|c|c|c|c|}
\hline $\begin{array}{c}\text { Name of } \\
\text { mine }\end{array}$ & $\begin{array}{l}\text { No. of } \\
\text { specimens }\end{array}$ & $\delta^{34} \mathrm{~S}(\% 0)$ & Ore minerals observed & Ore formation age \\
\hline \multicolumn{5}{|l|}{$A u-A g$} \\
\hline A Geumwang & 9 & +9.6 & py, aspy, sp, cp, acth, moly & \\
\hline B Mugug & 6 & 8.5 & py, cp, aspy, sp & Cretaceous* \\
\hline C Cheonbo & 4 & 6.2 & py, aspy, cp, gn, moly & Jurassic* \\
\hline D Seogyo & 9 & 5.8 & py, aspy, cp, gn, elec & Jurassic* \\
\hline E Namchang & 12 & 7.0 & aspy, py, gn & Jurassic* \\
\hline F Samgwang & 13 & 3.6 & aspy, sp, gn, cp, py & \\
\hline G Gubong & 14 & 5.9 & po, gn, sp, py, aspy, elec & \\
\hline H Gyeolseong & 7,6 & $5.7,5.2$ & py, gn, cp, sp, po, aspy & \\
\hline I Imcheon & 11 & 4.4 & py, sp, cp, gn, acth & Cretaceous* \\
\hline J Jeonjuil & 10 & 4.9 & py, acth & \\
\hline K Deogon & 13 & 5.4 & py, gn, sp, cp, elec, aspy & Cretaceous** \\
\hline L Yanghang & 3 & 3.1 & py, sp, cp, gn, po, elec & Cretaceous* \\
\hline M Baekjin & 7 & 5.3 & py, sp, gn, cp, aspy & \\
\hline N Gwangyang & 6 & 2.3 & $\mathrm{cp}, \mathrm{py}, \mathrm{sp}, \mathrm{po}, \mathrm{gn}$ & Cretaceous** \\
\hline 0 Sanggeum & 6 & 3.7 & py, sp, cp, moly & Cretaceous** \\
\hline P Geumjeong & 26 & 4.8 & py, cp, aspy, po & pre-Cambrian* \\
\hline Q Dadeuk & 6 & 4.6 & sp, gn, py, cp, aspy & \\
\hline \multicolumn{5}{|l|}{ W-Mo } \\
\hline R Garisan & 8 & 2.1 & py, cp, sp, gn, po, wolf, nabi & \\
\hline S Daehwa & 13 & 4.2 & $\mathrm{cp}, \mathrm{py}, \mathrm{po}, \mathrm{sp}$, moly, wolf & Cretaceous*** \\
\hline T Cheongyang & 15 & 4.7 & $\mathrm{cp}, \mathrm{py}, \mathrm{po}, \mathrm{sp}$, moly, wolf, nabi & \\
\hline U Jangsu & 7 & 4.3 & moly, cp, sp, nabi & \\
\hline V Ssangjeon & 9 & 1.0 & py, aspy & \\
\hline W Ogbang & 4 & -0.5 & po, py, cp & \\
\hline \multicolumn{5}{|l|}{$F$} \\
\hline X Jinrag & 3 & 15.4 & py, cp, po, sp & \\
\hline \multicolumn{5}{|c|}{$\begin{array}{l}\text { Abbreviations acth: acanthite, aspy: arsen } \\
\text { trum, gn: galena, moly: molybdenite, nab } \\
\text { pyrite, sp: sphalerite, wolf: wolframite } \\
\text { * Shimazaki et al. (unpublished data). } \\
\text { ** Estimated from geological evidences. } \\
\text { *** Kaneoka et al. }(1983), \text { Shibata et al. }(1983\end{array}$} \\
\hline
\end{tabular}

Japan and Korea for comparison. The large positive $\delta^{34} \mathrm{~S}$ value for the Jinrag deposit, could be explained only assuming the participation of sulfate sulfur in the extraction and/or transportation process of sulfur by the hydrothermal solution.

All the data obtained by the present study and by Sato et al. (1981b), are plotted together in Fig. 2 and histograms of $\delta^{34} \mathrm{~S}$ values are given in Fig. 3. These figures demonstrate the following characteristics of ore sulfur in the southern Korean Peninsula: 1) although some exceptions are present, most $\delta^{34} \mathrm{~S}$ values fall in the narrow range of +2 to $+7 \%$, and 2 ) no systematic variations are observed among the deposits of different geologic environments, and with dif- ferent workable metals.

As shown in Fig. 1, the Bulgugsa granitic rocks are distributed mainly in and around the Gyeongsang Basin. No isotopic variations, however, are recognized among ore sulfur from the deposits in and out of the Basin (Fig. 3). In addition, the present data confirm that some deposits associated with the Jurassic ilmenite series granitic rocks have ore sulfur with positive isotopic values. The sulfur isotope systematics established in Japan by Sasaki and Ishihara (1979, 1980) might not be applicable to the southern Korean Peninsula. A more acceptable explanation, however, is to assume rock sulfur with positive isotopic values for the Jurassic ilmenite series granitic rocks in South Korea. 


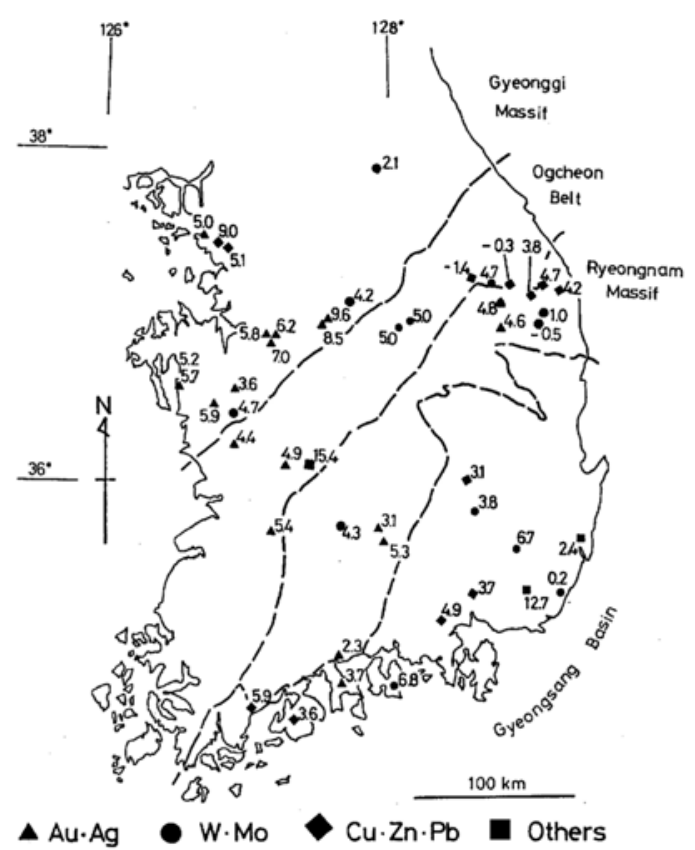

Fig. 2. $\delta^{34} S$ values in per mil for ore sulfur from the representative deposits in South Korea. Data are taken from this study (24 deposits) and Sato et al. (1981b) (22 deposits).

As has been mentioned by Sasaki and Ishihara (1979), the crustal sulfur may have remarkably heavy isotopic values in continental regions. The ilmenite series granitic rocks in such regions do not necessarily have negative $\delta^{34} \mathrm{~S}$ values. Further works on whole rock sulfur of the Korean granitic rocks are indispensable to discuss the genetical relation between the ore and rock sulfur.

The sulfur isotope data on individual sulfide minerals from some base metal and W-Mo deposits are given in several previous works (Kim and Nakai, 1980, 1982; So and Shelton, 1983; So et al., 1983a,b,c, 1984). Throughout all data available to date, including those on composite samples and individual minerals, it is remarkable that only a few deposits in South Korea have ore sulfur with negative $\delta^{34} \mathrm{~S}$ values. They include the Ogbang W-Mo (W: $-0.5 \%$ ), Shinyemi $\mathrm{Zn}$ $\mathrm{Pb}-\mathrm{Mo}(-1.4 \%$ : Sato et al., 1981b), Geodo Cu$\mathrm{Fe}(-0.3 \%$ : Sato et al., 1981b) and Youngduck $\mathrm{Zn}-\mathrm{Pb}(-2.0$ to $-2.5 \%$ : Kim and Nakai,
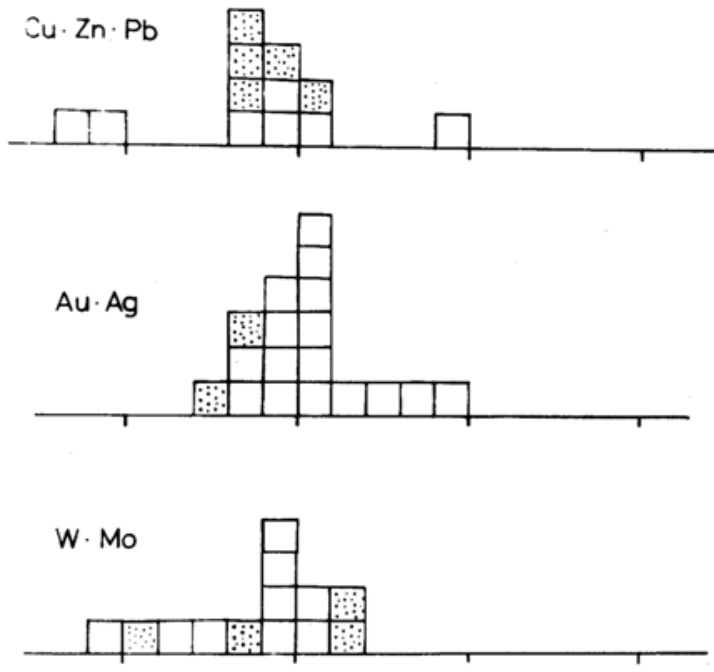

Others

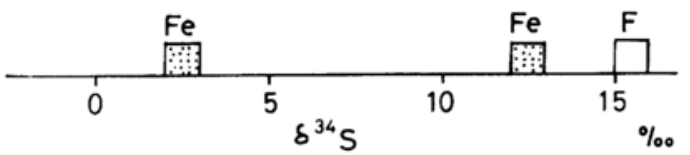

Fig. 3. Histograms of isotopic compositions of ore sulfur from 46 representative deposits in South Korea, compiled from Fig. 2. Dotted boxes show the deposits present in the Cretaceous Gyeongsang Basin.

1980). It is noteworthy that these deposits locate near the northeastern end of the southern Korean Peninsula, known as the Taebaegsan area. In the Sambo $\mathrm{Zn}-\mathrm{Pb}$ deposit, significantly light sulfide sulfur, -4.0 to $-12.1 \%$ of $\delta^{34} \mathrm{~S}$ values, is reported by Kim and Nakai (1980) and So et al. (1984). According to them, however, associated barite has heavy sulfur, +14.7 to $+19.5 \%$, and the average isotopic composition of sulfur precipitated in the deposit is estimated to be about $+5 \%$ o (Kim and Nakai, 1980).

As has already been noted by Sasaki and Ishihara $(1979,1980)$, the isotopic trend of ore and rock sulfur for ilmenite series granitic rocks in Japan, could be explained by the incorporation of crustal sulfur enriched in ${ }^{32} \mathrm{~S}$. Predominance of ore sulfur with positive $\delta^{34} \mathrm{~S}$ values in South Korea, suggests a scarcity of clastic sediments with biogenic sulfur in the Korean con- 
tinental crust. Limited distribution of deposits with isotopically light ore sulfur just mentioned, may indicate the variation of constituent sedimentary rocks in the basement.

Acknowledgements-The authors are much indebted to Mr. Fumitaka Yanagisawa of the Institute for Thermal Spring Research, Okayama University, for his help with the experiments. Thanks are also due to Dr. Moon Young Kim of Korean Institute of Energy and Resources, and Dr. Hyo Taek Chon of College of Engineering, Seoul National University for their kind support during the field survey. The present paper is a part of the result obtained in the Second Overseas Field Research on the southern Korean Peninsula, sponsored by a Grant-in-Aid from the Ministry of Education of Japan. The authors wish to thank Professor Akio Tsusue of Kumamoto University for the organization of the project.

\section{REFERENCES}

Farrar, E., Clark, A. H. and Kim, O. J. (1978) Age of the Sangdong tungsten deposit, Republic of Korea, and its bearing on the metallogeny of the southern Korean Peninsula. Econ. Geol. 73, 547-566.

Fletcher, C. J. N. and Rundle, C. C. (1977) Age of mineralization at Sannae and Ilkwang mines, Gyeongsang Basin, Republic of Korea. J. Geol. Soc. Korea 13, 71-75.

Gallagher, D. (1963) Mineral resources of Korea. vols. 1-6. Mining Branch, Industry and Mining Division USOM/Korea.

Ishihara, S. (1977) The magnetite-series and ilmeniteseries granitic rocks. Kozan Chishitsu 27, 293-305.

Ishihara, S., Lee, D. S. and Kim, S. Y. (1981) Comparative study of Mesozoic granitoids and related WMo mineralization in southern Korea and southwestern Japan. Kozan Chishitsu 31, 311-320.

Kaneoka, I., Shimazaki, H. and Lee, M. S. (1983) Estimation of ore formation ages by the ${ }^{40} \mathrm{Ar}-{ }^{39} \mathrm{Ar}$ method. Abstr. Annual Meeting Geochem. Soc. Japan 1983, 102 (Japanese).

Kim, K. H. and Nakai, N. (1980) Sulfur isotope composition and isotopic temperatures of some base metal ore deposits, South Korea. J. Geol. Soc. Korea 16, 124-134 (Korean).

Kim, K. H. and Nakai, N. (1982) Sulfur isotope composition and isotopic temperatures of the Shinyemi lead and zinc ore deposits, western Taebaegsan metallogenic belt, Korea. J. Korean Inst. Mining Geol. 15, $155-166$.

Kim, O. J. (1971a) Study on the intrusion epochs of younger granites and their bearing to orogenies in
South Korea. J. Korean Inst. Mining Geol. 4, 1-9 (Korean).

Kim, O. J. (1971b) Metallogenic epochs and provinces of South Korea. J. Geol. Soc. Korea 7, 37-59.

Lee, M. S. (1981) Geology and metallic mineralization associated with Mesozoic granitic magmatism in South Korea. Kozan Chishitsu 31, 235-244.

Mizuta, T., Shimazaki, H., Kaneda, H. and Lee, M. S. (1984) Compositional variation of sphalerites from some $\mathrm{Au}-\mathrm{Ag}$ ore deposits in South Korea. Granitic province and associated ore deposits in South Korea. Rept. of 2nd Overseas Field Research on the Southern Korean Peninsula. 127-152. Edited by A. Tsusue.

Reedman, A. J. and Um, S. H. (1975) The geology of Korea. Geol. Mineral Inst. Korea.

Sakai, H., Matsubaya, O. and Nakajima, Y. (1970) On the new McKinney type mass spectrometer recently installed in the Institute for Thermal Spring Research, Okayama University. Mass Spectroscopy 18, 1195-1204.

Sasaki, A. and Ishihara, S. (1979) Sulfur isotopic composition of the magnetite-series and ilmeniteseries granitoids in Japan. Contrib. Mineral. Petrol. $68,107-115$.

Sasaki, A. and Ishihara, S. (1980) Sulfur isotopic characteristics of granitoids and related mineral deposits in Japan. Proc. 5th IAGOD Symp. 1,325335.

Sato, K. (1980) - Distribution of fluorite deposits in Japanese Islands. Mineral. Deposita 15, 327-334.

Sato, K., Shibata, K., Uchiumi, S. and Shimazaki, H. (1981a) Mineralization age of the Shinyemi $\mathrm{Zn}$ $\mathrm{Pb}-\mathrm{Mo}$ deposit in the Taebaegsan area, southern Korea. Kozan Chishitsu 31, 333-336.

Sato, K., Shimazaki, H. and Chon, H. T. (1981b) Sulfur isotopes of the ore deposits related to felsic magmatism in the southern Korean Peninsula. Kozan Chishitsu 31, 321-326.

Shibata, K., Park, N. Y., Uchiumi, S. and Ishihara, S. (1983) K-Ar ages of the Jecheon granitic complex and related molybdenite deposits in South Korea. Kozan Chishitsu 33, 193-197.

Shimazaki, H., Kaneda, H. and Lee, M. S. (1984) Mineralization associated with Mesozoic felsic magmatism in Korea. Granitic provinces and associated ore deposits in South Korea. Rept. of 2nd Overseas Field Research on the Southern Korean Peninsula. 35-60. Edited by A. Tsusue.

Shimazaki, H., Sato, K. and Chon, H. T. (1981) Mineralization associated with Mesozoic felsic magmatism in Japan and Korea. Kozan Chishitsu 31, 297-310. So, C. S. and Shelton, K. L. (1983) A sulfur isotopic and fluid inclusion study of the Cu-W-bearing tourmaline breccia pipe, Ilkwang mine, Republic of Korea. 
Econ. Geol. 78, 326-332.

So, C. S., Rye, D. M. and Shelton, K. L. (1983a) Carbon, hydrogen, oxygen, and sulfur isotope and fluid inclusion study of the Weolag tungsten-molybdenum deposit, Republic of Korea: Fluid histories of metamorphic and ore-forming events. Econ. Geol. 78, 155-1573.

So, C. S., Shelton, K. L. and Rye, D. M. (1983b) Geologic, sulfur isotopic, and fluid inclusion study of the Ssang Jeon tungsten mine, Republic of Korea. Econ. Geol. 78, 157-163.

So, C. S., Shelton, K. L., Seidemann, D. E. and Skinner, B. J. (1983c) The Dae Hwa tungsten-molybdenum mine, Republic of Korea: A geochemical study. Econ. Geol. 78, 920-930.
So, C. S., Park, M. E., Shelton, K. L. and Seidemann, D. E. (1984) Geology and geochemistry of the Sambo $\mathrm{Pb}-\mathrm{Zn}$ deposit, Republic of Korea. Econ. Geol. 79, 656-670.

Yanagisawa, F. and Sakai, H. (1983) Thermal decomposition of barium sulfate - vanadium pentaoxide silica glass mixtures for preparation of sulfur dioxide in sulfur isotope ratio measurements. Anal. Chem. 55, 985-987.

Yun, S. K. and Silberman, M. L. (1979) K-Ar geochronology of igneous rocks in the Yeonhwa-Ulchin zinc-lead district and southern margin of the Taebaegsan Basin, Korea. J. Geol. Soc. Korea 15, 89-99. 